\title{
Screening of arsenic tolerance in rice at germination and early seedling stage as influenced by sodium arsenate
}

\author{
Md. Abdul Halim*, Maitry Ghosh, Meher Nigar, Feroza Hossain and \\ Nahid Akhter \\ Plant Physiology and Plant Biochemistry Laboratory, Department of Botany, \\ Jahangirnagar University, Savar, Dhaka-1342, Bangladesh
}

\begin{abstract}
Arsenic contamination in rice would be a serious problem for human health. A screening program was conducted at germination and early seedling stage of rice cultivars which were grown under plate culture and hydroponic culture condition. Five different concentrations of arsenate viz. $\mathrm{T}_{1}(1 \mathrm{ppm}), \mathrm{T}_{2}(3 \mathrm{ppm}), \mathrm{T}_{3}(6 \mathrm{ppm}), \mathrm{T}_{4}(9 \mathrm{ppm}), \mathrm{T}_{5}(12 \mathrm{ppm})$ and distilled water (control) were applied on seven cultivars of rice such as BR-26, BRRI-28, BRRI-29, BRRI-45, BRRI-50, BR-3 and BR-14. The germination percentage and tolerant percentage, root length and shoot length and biomass or seedling dry weight decreased significantly with the increase of arsenic levels.Among seven cultivars, BRRI-29 showed the maximum percentage of germination and tolerant percentage, BR-26 produced the highest root length and shoot length to highest arsenic concentration (12 ppm) whereas maximum biomass was obtained for BR-14.
\end{abstract}

Key words: Sodium arsenate, rice cultivars, germination, root length, biomass, seedling stage

\section{INTRODUCTION}

Arsenic contamination of groundwater is a severe problem in Bangladesh and this has affected at least 25 million people (Ravenscroft et al., 2005). Next to drinking water, rice could be a potential source of arsenic exposure of the people living in the arsenic affected areas of Bangladesh (Hossain et al., 2008, Panaullah et al., 2009, William et al., 2009). Roberts et al.(2007) estimated that over 1000 tons of arsenic might be transferred to arable land each year from arsenic contaminated groundwater irrigation, creating a potential risk for future agricultural sustainability and food security of the country. Arsenic may enter into human body directly through drinking water and indirectly through foods, chiefly rice for Bangladeshi people. Rice covers about $75 \%$ of the total cropped areas in the country. Many areas have high groundwater and soil arsenic contents which are likely to be taken up by plants through roots and transported to the aerial portion. The concentration of arsenic in groundwater from the affected areas have very large range from $<0.5$ to $>3200 \mu \mathrm{g} / \mathrm{L}$ (Smedley \& Killiburgh, 2002). In Bangladesh, large numbers of shallow tube wells and deep tubewells are being used to irrigate about 4.3

\footnotetext{
* Corresponding author: E-mail:mahalim21@yahoo.com
} 
million hac. which contribute significantly to the country's food grain production (Rashid et al., 2004). As-contaminated groundwater is used for irrigation as well as for drinking. The World Health Organization provisional guideline value for drinking water is 0.01 $\mathrm{mg} / \mathrm{kg}$. There are concerns that arsenic may be absorbed by plants, particularly cereals, entering the grains and thus the food chain. Therefore arsenic poisoning of human beings and livestock occur frequently (Chun-xi et al., 2006). Arsenic (As) toxicity to rice can threaten food security in countries such as Bangladesh where rice is the major staple food and arsenic contamination of irrigation waters and soil is widespread (Panaullah et al., 2013).The concentration levels of different arsenic species in rice heavily depends on environmental conditions and to a lesser extend on genotype of the rice plants (EVISA, 2013).

Plants can develop toxicity symptoms while they are exposed to excess arsenic either in soil or in solution culture such as: inhibition of seed germination (Abedin and Meharg, 2002); decrease in plant height (Marin et al., 1992; Carbonel-Barrachina et al., 1995; Abedin et al., 2002b; Jahan et al., 2003a) ); reduction in root growth (CarbonelBarrachina et al., 1998; Abedin et al.,2002); decrease in shoot growth (Cox et al., 1996; Carbonel-Barrachina et al.,1998); sometimes leading to death (Baker et al., 1976; Marin et al., 1992). In hyper accumulator species, arsenic increases antioxidant mechanisms, both enzymatic and non-enzymatic, leading to its detoxification and subsequent hyper accumulation in the tissue (Srivastava et al., 2005; Singh et al., 2006). In contrast, in nonhypera ccumulators, arsenic induces an oxidative stress resulting in cellular damage in terms of enhanced lipid peroxidation, $\mathrm{H}_{2} \mathrm{O}_{2}$ accumulation and up-regulation of several scavenging enzymes (Hartley-Whitaker et al., 2001; Mascher et al., 2002).Germination energy, germination percentage, germination index, vitality index, length and biomass of root and shoot all displayed decreasing trend with increasing concentrations of arsenic. Reduced root length growth in response to arsenic exposure has been reported by a number of investigators in other plants (Hartley-Whitaker et al., 2001 and CarbonellBarrachina et al., 1998).

Germination and early seedling stage of rice is more sensitive than that of any other growth stages. Therefore an attempt has been taken to study the effect of arsenate on germination of seeds, and early growth of seedlings on seven rice cultivars.

\section{MATERIALS AND METHODS}

Rice Cultivars: Seven cultivars of rice (BR-26, BRRI-28, BRRI-29, BRRI-45, BRRI-50, BR-3 and BR-14) were collected from BRRI, Gazipur, Dhaka, Bangladesh.

Treatmeants: Following the previous research information (Carbonell-Barrachina and Burló-Carbonell $2_{2}$ 1997) five concentrations of arsenic (As) (source $\mathrm{Na}_{2} \mathrm{HAsO}_{4} \cdot 7 \mathrm{H}_{2} \mathrm{O}$ ) solution, $\mathrm{T}_{1}=1 \mathrm{ppm}, \mathrm{T}_{2}=3 \mathrm{ppm}, \mathrm{T}_{3}=6 \mathrm{ppm}, \mathrm{T}_{4}=9 \mathrm{ppm}$ and $\mathrm{T}_{5}=12 \mathrm{ppm}$ As and $\mathrm{T}_{0}=$ distilled water were used as control treatment. 
Both germination experiment and hydroponic culture were carried out in the Laboratory of Plant Physiology and Plant Biochemistry Lab. of Botany Department, Jahangirnagar University, during November, 2010 to April, 2011.

Germination Test: For germination experiment 20 seeds of each cultivar were placed separately on a blotter paper in a $9 \mathrm{~cm}$ diameter Petri dishe covered with a lid. The Petri dishes were kept under laboratory condition where temperature fluctuated between $32 \pm 2^{\circ} \mathrm{C}$. Petri dishes and blotter papers were soaked with $20 \mathrm{ml}$ arsenate solution of different concentrations (mentioned in the section treatments) and distilled water (as control) separately. The number of germinated seeds was recorded when both plumule and radical extended more than $2 \mathrm{~mm}$ from the seed coat. Germinated seeds were counted on the 2 nd day of germination and the results were expressed as percentage over control. Each treatment was replicated three times. The tolerance percentage was calculated after final germination with the following equation:

Tolerance percentage $=\frac{\text { Germination } \% \text { in each treatment }}{\text { Germination } \% \text { in the control }} \times 100$

Hydroponic culture for seedling growth: The seedling growth experiment was conducted by hydroponics culture under laboratory condition. Several plastic pots were taken and filled with $250 \mathrm{ml}$ of nutrient solution containing $5 \mathrm{mM} \mathrm{Ca}\left(\mathrm{NO}_{3}\right)_{2}$, $5 \mathrm{mM} \mathrm{KNO} 3,5 \mathrm{mM} \mathrm{K}_{2} \mathrm{SO}_{4}$ and $5 \mathrm{mM} \mathrm{KH}_{2} \mathrm{PO}_{4}$ in distilled water (Abbas et al., 2008). Five germinated seeds were placed in the hole of plastic nets attached with cork sheets and were then placed on the mouth of plastic pots. The outside of the plastic pots were painted with black colour. Deep coloured plastic beads were placed on the upper part of plastic net of each pot to prevent light from penetrating the solution.

Then the distilled water and different concentrations of arsenate $(1,3,6,9$ and12 ppm As) were added to the nutrient solution. The $\mathrm{pH}$ was adjusted to 5. For each treatment three replications were used. The plastic pots with germinated rice seedlings were then placed at room temperature $\left(32 \pm 2{ }^{\circ} \mathrm{C}\right)$ for 10 days. Root length and shoot length of ten days old seedlings were measured and biomass (dry weight/ten seedlings) of whole seedlings was measured after drying for 72 hours at $70^{\circ} \mathrm{C}$.

Statistical Analysis: Completely randomized design (CRD) was used for the experiment with three replications having six treatments and six cultivars. Recorded data of different parameters were statistically analyzed with the help of Microsoft Excel 2003 and Duncan's multiple range test (DMRT) was done by using SPSS Program 16. The mean treatment differences were evaluated by least significant difference test at 5\% level of significance (Gomez \& Gomez,1984). 


\section{RESULTS AND DISCUSSION}

The effects of arsenate on germination percentage, tolerance percentage, root and shoot growth, and biomass of rice cultivars obtained from this experiment are described below under following heads:

Germination percentage and tolerance percentage: The mean values of germination percentages and tolerance percentage of seven varieties of rice are presented in Table1and 2. The results show a decreasing tendency of the germination percentage and tolerance percentage with the increase of concentration of arsenate (Table1 and 2). Among seven varieties of rice, BD-29 showed highest germination percentage for all treatments. At the highest arsenate level $\left(\mathrm{T}_{5}=12 \mathrm{ppm}\right)$ germination Percentages of BRRI-29, BR-26, BR-3, BRRI-28, BRRI-45, BRRI-50 and BR-14 were 82.22, 68.89, 57.78, 71.11, 74.44, 76.67 and 76.67 respectively while their tolerance percentages were $87.06,72.95,63.42,78.05$, $85.89,85.19$ and 84.15 respectively. Therefore, BRRI-29 showdthe highest germination and tolerant percentage, while BR-14, BRRI-50, BRRI-45 and BRRI-28 showed moderate results and the lowest rate of germination and tolerant percentages were found in BR-3 and BR-26 respectively for the highest As treatment. From the CV \% (Table1) it can be showed that the Germination Percentage of BR-29 is more homogeneous and germination percentage of BR-3 is more scattered. Arsenic is not essential for plants but higher concentrations of arsenic interfered with metabolic processes and inhibited seed germination, plant growth and development through arsenic induced phytotoxicity (Marin et al., 1993a, Abedin \& Meharg, 2002).They also reported that germination and early seedling growth of rice decreased significantly with increasing concentrations of arsenic. Seed germination and the early seedling growth are more sensitive to metal pollution because some of the defense mechanisms have not developed such as, starch, storage energy of germinating seeds does not degrade predominantly via the amylolytic pathway (Swain \& Dekker, 1966a)

Root and Shoot growth: Root length was recorded 10 days after the germination of seeds. It was measured up to $12 \mathrm{ppm}$ of arsenate treatment and found that the root length was decreased from $107.74 \mathrm{~mm}$ for the control to $70.46 \mathrm{~mm}$ for the $12 \mathrm{ppm}$ arsenate treatment (Table 3). The reduction of root length had started from arsenate 1ppm treatment (Table 3). At the highest level of arsenate treatment (12ppm) the average values for root lengths found to be $60.7,90.30,61.60,83.00,61.80,60.10$ and $75.7 \mathrm{~mm}$ for BRRI-29, BR-26, BR-3, BRRI-28, BRRI-45, BRRI-50 and BR-14 respectively. Thus BR26 had relatively the longest root followed by BRRI-28, while BRRI-50 had the shortest root. From the CV (\%) (Table 3) it can be seen that the root lengths of BR-3 are more scattered compare to other cultivars and that of BRRI-28 are more homogeneous.

Shoot length was recorded after 10 days of emergence of radicals. Almost all the varieties show healthy seedlings but with the increase in arsenate concentration the mean shoot length of all rice cultivars decreased significantly (Table 4). Seedling heights or shoot lengths were recorded upto arsenate $12 \mathrm{ppm}$. For the control (0ppm) BRRI-28 produced the longest plants followed by BR-26. For the highest level of arsenate (12ppm) concentration the mean values for seedling heights were $53 \mathrm{~mm}$ for BRRI-29, $80.75 \mathrm{~mm}$ for BRRI-26, $51.90 \mathrm{~mm}$ for BR-3, $66.70 \mathrm{~mm}$ for BRRI-28, $59.75 \mathrm{~mm}$ for BRRI-45, 60.10 
$\mathrm{mm}$ for BRRI-50 and $64.35 \mathrm{~mm}$ for BR-14. BR-26 produced the longest seedling while BR-3 produced the shortest for $12 \mathrm{ppm}$ As. Arsenate decreased the shoot length from $98.64 \mathrm{~mm}$ (control) to $61.85 \mathrm{~mm}$ for $12 \mathrm{ppm}$ arsenate treatment. It can be seen that among all cultivars for all treatments the mean (Cultivar mean) shoot length of BRRI-29 is the shortest $(68.60 \mathrm{~mm})$ and the longest is for BR-26 $(94.90 \mathrm{~mm})$. From the CV $(\%)$ (Table 4) it can be seen that the shoot lengths of BR-3 was more scattered than that of other cultivars and the shoot lengths of BRRI-28 and BRRI-45 were more homogeneous.

Table 1. Effect of different levels of arsenate on germination percentage of seven rice cultivars

\begin{tabular}{|c|c|c|c|c|c|c|c|c|}
\hline \multirow{2}{*}{$\begin{array}{l}\text { Treat- } \\
\text { ments }\end{array}$} & \multicolumn{7}{|c|}{ Cultivars } & \multirow{2}{*}{$\begin{array}{l}\text { Treat } \\
\text { ment } \\
\text { mean }\end{array}$} \\
\hline & BRRI -29 & BR-26 & BR-3 & BRRI -28 & BRRI -45 & BRRI -50 & BR-14 & \\
\hline T0 & $94.44 \pm$ & $94.44 \pm$ & $91.11 \pm$ & $91.11 \pm$ & $86.67 \pm$ & $90.00 \pm$ & $91.11 \pm$ & 91.27 \\
\hline $\mathrm{T} 1$ & $88.89 \pm$ & $78.89 \pm$ & $86.67 \pm$ & $88.89 \pm$ & $78.89 \pm$ & $88.89 \pm$ & $84.44 \pm$ & 85.08 \\
\hline & 2.94abc & $2.94 b c$ & $3.33 b$ & $78.89 b c$ & $1.11 \mathrm{ab}$ & $1.11 \mathrm{~b}$ & $4.48 \mathrm{~cd}$ & \\
\hline $\mathrm{T} 2$ & $\begin{array}{l}91.11 \pm \\
2.22 \mathrm{bc}\end{array}$ & $\begin{array}{l}73.33 \pm \\
1.92 \mathrm{ab}\end{array}$ & $\begin{array}{c}86.67 \pm \\
3.45 \mathrm{~b}\end{array}$ & $\begin{array}{l}85.56 \pm \\
1.11 b c\end{array}$ & $\begin{array}{l}82.22 \pm \\
4.84 a b\end{array}$ & $\begin{array}{l}86.67 \pm \\
1.95 \mathrm{ab}\end{array}$ & $\begin{array}{c}81.1 \pm \\
1.11 \mathrm{bc}\end{array}$ & 83.81 \\
\hline T3 & $\begin{array}{l}84.44 \pm \\
1.11 \mathrm{ab}\end{array}$ & $\begin{array}{l}75.55 \pm \\
1.11 \mathrm{ab}\end{array}$ & $\begin{array}{c}82.22 \pm \\
1.11 \mathrm{~b}\end{array}$ & $\begin{array}{c}78.89 \pm \\
2.9 \mathrm{ab}\end{array}$ & $\begin{array}{l}77.78 \pm \\
2.94 \mathrm{ab}\end{array}$ & $\begin{array}{l}83.33 \pm \\
5.09 \mathrm{ab}\end{array}$ & $\begin{array}{l}76.67 \pm \\
1.92 \mathrm{bc}\end{array}$ & 79.84 \\
\hline $\mathrm{T} 4$ & $\begin{array}{c}83.33 \pm \\
1.93 \mathrm{a}\end{array}$ & $\begin{array}{c}68.89 \pm \\
2.94 \mathrm{a}\end{array}$ & $\begin{array}{c}78.89 \pm \\
1.11 \mathrm{~b}\end{array}$ & $\begin{array}{l}78.89 \pm \\
6.19 \mathrm{ab}\end{array}$ & $\begin{array}{l}75.56 \pm \\
4.01 \mathrm{ab}\end{array}$ & $\begin{array}{l}80.00 \pm \\
3.85 \mathrm{ab}\end{array}$ & $\begin{array}{l}80.00 \pm \\
3.58 \mathrm{ab}\end{array}$ & 77.14 \\
\hline T5 & $\begin{array}{c}82.22 \pm \\
1.11 \mathrm{a}\end{array}$ & $\begin{array}{c}68.89 \pm \\
2.94 \mathrm{a}\end{array}$ & $\begin{array}{l}57.78 \pm \\
13.92 \mathrm{a}\end{array}$ & $\begin{array}{c}71.11 \pm \\
2.94 \mathrm{a}\end{array}$ & $\begin{array}{c}74.44 \pm \\
2.22 \mathrm{a}\end{array}$ & $\begin{array}{c}76.67 \pm \\
3.85 \mathrm{a}\end{array}$ & $\begin{array}{c}76.67 \pm \\
3.85 \mathrm{a}\end{array}$ & 70.48 \\
\hline $\begin{array}{l}\text { Cultivar } \\
\text { Mean } \\
\text { LSD }\end{array}$ & 87.41 & 76.67 & 80.56 & 82.41 & 79.26 & 84.26 & 78.33 & \\
\hline $\begin{array}{c}(\mathrm{p}<0.0 \\
5)\end{array}$ & 3.22 & 3.79 & 9.02 & 4.93 & 4.88 & 4.83 & 4.48 & \\
\hline CV\% & 6.35 & 12.65 & 17.74 & 10.36 & 8.10 & 8.12 & 13.08 & \\
\hline
\end{tabular}

In a column followed by common small letters do not differ significantly at $5 \%$ level.

Carbonell-Barrachina et al. (1998) showed that the growth of root and shoot was inhibited by high concentrations $(5-20 \mathrm{mg} / \mathrm{kg})$ arsenic treatment. The inhibition was stronger in the roots than in the shoots when treated with arsenic (Wang et al., 2002). The reasons are that the plant roots are the first point of contact for these toxic arsenic species in the nutrient media (Abedin \& Meharg, 2002) and the uptake of nutrition is inhibited in roots, as a result the growth of the whole plant is constrained (Mitchell \& Barr, 1995).

Biomass: At the low level of arsenate ( $\left.T_{1}=1 \mathrm{ppm}\right), \mathrm{BR}-26, \mathrm{BR}-3, \mathrm{BRRI}-45, \mathrm{BRRI}-50$ and BR-14 cultivars were started to decrease the biomass of seedlings. With the increase of arsenate levels the biomass decreased from $0.0793 \mathrm{gm} / \mathrm{ten}$ seedlings for the control and reduced to $0.0594 \mathrm{gm} /$ ten seedlings with $12 \mathrm{ppm}\left(\mathrm{T}_{5}\right)$ arsenate. The mean biomass at $12 \mathrm{ppm}\left(\mathrm{T}_{5}\right)$ arsenate was $0.044 \mathrm{gm}$ for BRRI-29, $0.0595 \mathrm{gm}$ for BR-26, $0.0665 \mathrm{gm}$ for BR-3, $0.0665 \mathrm{gm}$ for BRRI-28, $0.063 \mathrm{gm}$ for BRRI-45, $0.0445 \mathrm{gm}$ for BRRI-50 and 0.0705 gm for BR-14 (Figure 1). Therefore BR-14 had highest biomass followed by BR3, while BRRI-29 had the lowest biomass followed by BRRI-50. The result, however, 
that BR-14 had the highest biomass for the arsenate 12ppm $\left(\mathrm{T}_{5}\right)$ treatment and BRRI-29 had the lowest. In this experiment, rice plants subjected to higher arsenate treatment produced lower biomass. There are number of reports of reduced shoot biomass/growth (Milam et al., 1988 and Marin et al.1993a) and root biomass (Abedin et al., 2002) in rice. However the result of the present study agrees with the results of those researchers.

Table 2. Effect of different levels of arsenate on tolerant percentage of seven rice cultivars

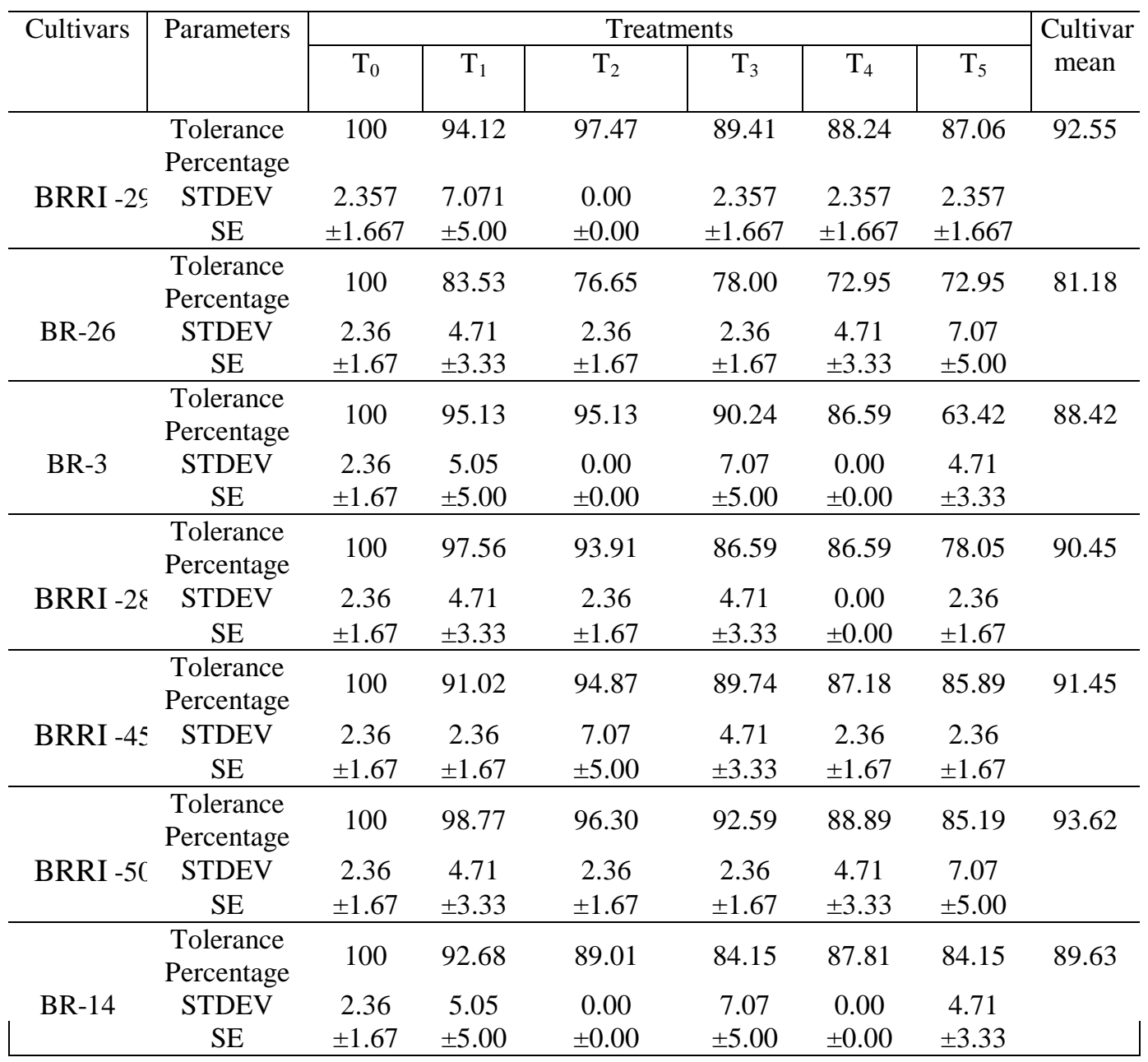

Note: STDEV means Standard Deviation and SE means Standard Error

Therefore, it can be concluded from the results of the present study that arsenic is highly toxic and very sensitive at germination and seedling growth stage of rice when they are exposed to arsenic. But the severity of arsenic toxicity depends on rice genotypes or cultivars and in various concentrations of arsenic. All the rice cultivars used in this study showed decreasing germination percentage, tolerance percentage, root and shoot length and dry weight with increasing concentration of arsenic level. Therefore BRRI-29, BR-26 and BR-14 rice cultivars may be selected as arsenic tolerant rice regarding germination and tolerant percentage, root and shoot length and biomass of seedlings respectively. 
Table 3. Effect of different labels of arsenate on root length $(\mathrm{mm})$ of seven rice cultivars

\begin{tabular}{|c|c|c|c|c|c|c|c|c|}
\hline \multirow{2}{*}{$\begin{array}{l}\text { Treatm- } \\
\text { ents }\end{array}$} & \multicolumn{7}{|c|}{ Cultivars } & \multirow{2}{*}{$\begin{array}{l}\text { Treat } \\
\text { ment } \\
\text { mean }\end{array}$} \\
\hline & BRRI -29 & BR-26 & BR-3 & BRRI -28 & BRRI -45 & BRRI -50 & BR-14 & \\
\hline \multirow[t]{2}{*}{ T0 } & $114.6 \pm$ & $120.9 \pm$ & $98.75 \pm$ & $107.15 \pm$ & $124.8 \pm$ & $83.40 \pm$ & $104.55 \pm$ & \multirow[t]{2}{*}{107.74} \\
\hline & $3.09 \mathrm{c}$ & $2.66 c$ & $4.52 c$ & $2.15 \mathrm{~d}$ & $3.45 \mathrm{~d}$ & $4.42 \mathrm{~d}$ & $3.06 \mathrm{c}$ & \\
\hline \multirow[t]{2}{*}{$\mathrm{T} 1$} & $110.8 \pm$ & $118.65 \pm$ & $82.10 \pm$ & $104.25 \pm$ & $101.90 \pm$ & $79.05 \pm$ & $97.75 \pm$ & \multirow[t]{2}{*}{99.21} \\
\hline & $3.60 \mathrm{c}$ & $3.25 \mathrm{c}$ & $4.11 b$ & $3.39 \mathrm{~d}$ & $5.09 \mathrm{c}$ & $3.20 b c$ & $4.68 b c$ & \\
\hline \multirow[t]{2}{*}{$\mathrm{T} 2$} & $104.65 \pm$ & $117.05 \pm$ & $80.45 \pm$ & $99.55 \pm$ & $98.45 \pm$ & $69.65 \pm$ & $95.95 \pm$ & \multirow[t]{2}{*}{95.11} \\
\hline & $2.0 \mathrm{c}$ & $2.58 \mathrm{c}$ & $5.07 \mathrm{~b}$ & $3.52 \mathrm{~cd}$ & $4.96 c$ & $4.35 \mathrm{ab}$ & $4.35 b c$ & \\
\hline \multirow[t]{2}{*}{$\mathrm{T} 3$} & $86.3 \pm$ & $108.3 \pm$ & $78.7 \pm$ & $94.55 \pm$ & $94.50 \pm$ & $67.45 \pm$ & $89.9 \pm$ & \multirow[t]{2}{*}{88.53} \\
\hline & $5.22 \mathrm{~b}$ & $4.36 b c$ & $6.96 \mathrm{~b}$ & $2.32 \mathrm{bc}$ & $2.70 b c$ & $4.50 \mathrm{a}$ & $4.85 b$ & \\
\hline \multirow[t]{2}{*}{$\mathrm{T} 4$} & $82.5 \pm$ & $102.65 \pm$ & $77.00 \pm$ & $86.05 \pm$ & $84.60 \pm$ & $62.40 \pm$ & $86.9 \pm$ & \multirow[t]{2}{*}{83.56} \\
\hline & $4.32 b$ & $5.09 \mathrm{~b}$ & $3.49 \mathrm{~b}$ & $2.43 \mathrm{ab}$ & $3.99 b$ & $3.05 \mathrm{a}$ & $5.59 \mathrm{ab}$ & \\
\hline \multirow[t]{2}{*}{ T5 } & $60.7 \pm$ & $90.30 \pm$ & $61.60 \pm$ & $83.00 \pm$ & $61.80 \pm$ & $60.10 \pm$ & $75.7 \pm$ & \multirow[t]{3}{*}{70.46} \\
\hline & $5.22 \mathrm{a}$ & $6.01 \mathrm{a}$ & $3.69 \mathrm{a}$ & $4.31 \mathrm{a}$ & $5.03 \mathrm{a}$ & $2.30 \mathrm{a}$ & $4.19 \mathrm{a}$ & \\
\hline Mean & 93.26 & 109.64 & 79.77 & 95.76 & 94.34 & 70.34 & 91.79 & \\
\hline $\begin{array}{l}\mathrm{LSD}(\mathrm{p}< \\
0.05)\end{array}$ & 5.35 & 5.54 & 6.27 & 4.09 & 5.64 & 4.90 & 5.92 & \\
\hline CV\% & 27.8 & 19.5 & 29.6 & 17.05 & 28.4 & 26.2 & 23.8 & \\
\hline
\end{tabular}

In a column followed by common small letters do not differ significantly at $5 \%$ level.

Table 4. Effect of different levels of arsenate on Shoot length $(\mathrm{mm})$ of seven rice cultivars

\begin{tabular}{|c|c|c|c|c|c|c|c|c|}
\hline \multirow{2}{*}{$\begin{array}{l}\text { Treat } \\
\text { ments }\end{array}$} & \multicolumn{7}{|c|}{ Cultivars } & \multirow{2}{*}{$\begin{array}{c}\text { Treatme } \\
\text { nt } \\
\text { mean }\end{array}$} \\
\hline & $\begin{array}{c}\text { BRRI - } \\
29\end{array}$ & BR-26 & BR-3 & $\begin{array}{c}\text { BRRI - } \\
28\end{array}$ & $\begin{array}{c}\text { BRRI - } \\
45\end{array}$ & BRRI -50 & BR-14 & \\
\hline T0 & $\begin{array}{l}87.90 \pm \\
4.74 \mathrm{c}\end{array}$ & $\begin{array}{l}111.90 \pm \\
5.40 \mathrm{~b}\end{array}$ & $\begin{array}{l}91.55 \pm \\
6.80 \mathrm{c}\end{array}$ & $\begin{array}{l}124.40 \pm \\
4.86 \mathrm{~d}\end{array}$ & $\begin{array}{l}95.55 \pm \\
4.27 \mathrm{c}\end{array}$ & $\begin{array}{c}83.40 \pm \\
4.42 \mathrm{~d}\end{array}$ & $\begin{array}{l}98.90 \pm \\
5.07 \mathrm{c}\end{array}$ & 98.64 \\
\hline $\mathrm{T} 1$ & $\begin{array}{l}84.80 \pm \\
3.73 \mathrm{c}\end{array}$ & $\begin{array}{l}98.35 \pm \\
6.61 \mathrm{ab}\end{array}$ & $\begin{array}{l}72.25 \pm \\
7.10 \mathrm{~b}\end{array}$ & $\begin{array}{l}100.00 \pm \\
3.99 \mathrm{c}\end{array}$ & $\begin{array}{l}90.15 \pm \\
6.50 \mathrm{bc}\end{array}$ & $\begin{array}{l}79.05 \pm \\
3.20 \mathrm{bc}\end{array}$ & $\begin{array}{l}84.60 \pm \\
7.64 b c\end{array}$ & 86.41 \\
\hline $\mathrm{T} 2$ & $\begin{array}{l}69.85 \pm \\
3.83 \mathrm{~b}\end{array}$ & $\begin{array}{l}96.40 \pm \\
6.50 \mathrm{ab}\end{array}$ & $\begin{array}{l}68.55 \pm \\
5.54 \mathrm{ab}\end{array}$ & $\begin{array}{l}96.55 \pm \\
4.26 \mathrm{bc}\end{array}$ & $\begin{array}{l}88.35 \pm \\
4.10 b c\end{array}$ & $\begin{array}{c}69.65 \pm \\
4.35 \mathrm{ab}\end{array}$ & $\begin{array}{l}83.00 \pm \\
3.93 \mathrm{bc}\end{array}$ & 80.84 \\
\hline T3 & $\begin{array}{l}59.20 \pm \\
2.46 \mathrm{bc}\end{array}$ & $\begin{array}{l}92.15 \pm \\
3.88 \mathrm{ab}\end{array}$ & $\begin{array}{l}67.65 \pm \\
6.33 \mathrm{ab}\end{array}$ & $\begin{array}{l}94.75 \pm \\
4.10 b c\end{array}$ & $\begin{array}{l}82.80 \pm \\
2.53 b c\end{array}$ & $\begin{array}{c}67.45 \pm \\
4.50 \mathrm{a}\end{array}$ & $\begin{array}{l}82.15 \pm \\
8.89 b c\end{array}$ & 76.72 \\
\hline $\mathrm{T} 4$ & $\begin{array}{l}56.80 \pm \\
4.87 \mathrm{a}\end{array}$ & $\begin{array}{l}89.85 \pm \\
7.37 \mathrm{a}\end{array}$ & $\begin{array}{l}63.85 \pm \\
4.62 \mathrm{ab}\end{array}$ & $\begin{array}{l}84.05 \pm \\
4.28 \mathrm{~b}\end{array}$ & $\begin{array}{l}77.35 \pm \\
5.03 \mathrm{~b}\end{array}$ & $\begin{array}{c}62.40 \pm \\
3.05 \mathrm{a}\end{array}$ & $\begin{array}{l}71.90 \pm \\
4.48 \mathrm{ab}\end{array}$ & 71.62 \\
\hline T5 & $\begin{array}{l}53.00 \pm \\
5.61 \mathrm{a}\end{array}$ & $\begin{array}{l}80.75 \pm \\
10.00 \mathrm{a}\end{array}$ & $\begin{array}{l}51.90 \pm \\
4.73 \mathrm{a}\end{array}$ & $\begin{array}{l}66.70 \pm \\
6.10 \mathrm{a}\end{array}$ & $\begin{array}{l}59.75 \pm \\
4.43 \mathrm{a}\end{array}$ & $\begin{array}{c}60.10 \pm \\
2.30 \mathrm{a}\end{array}$ & $\begin{array}{l}64.35 \pm \\
5.25 \mathrm{a}\end{array}$ & 61.85 \\
\hline $\begin{array}{l}\text { Cultivar } \\
\text { Mean }\end{array}$ & 68.60 & 94.90 & 69.29 & 94.40 & 82.33 & 70.34 & 80.82 & \\
\hline $\begin{array}{c}\text { LSD } \\
(\mathrm{p}<0 . \\
05)\end{array}$ & 5.67 & 9.03 & 7.78 & 6.11 & 6.07 & 4.90 & 8.05 & \\
\hline CV\% & 34.02 & 33.3 & 41.2 & 28.4 & 28.4 & 26.2 & 35.9 & \\
\hline
\end{tabular}

In a column followed by common small letters do not differ significantly at $5 \%$ level. 


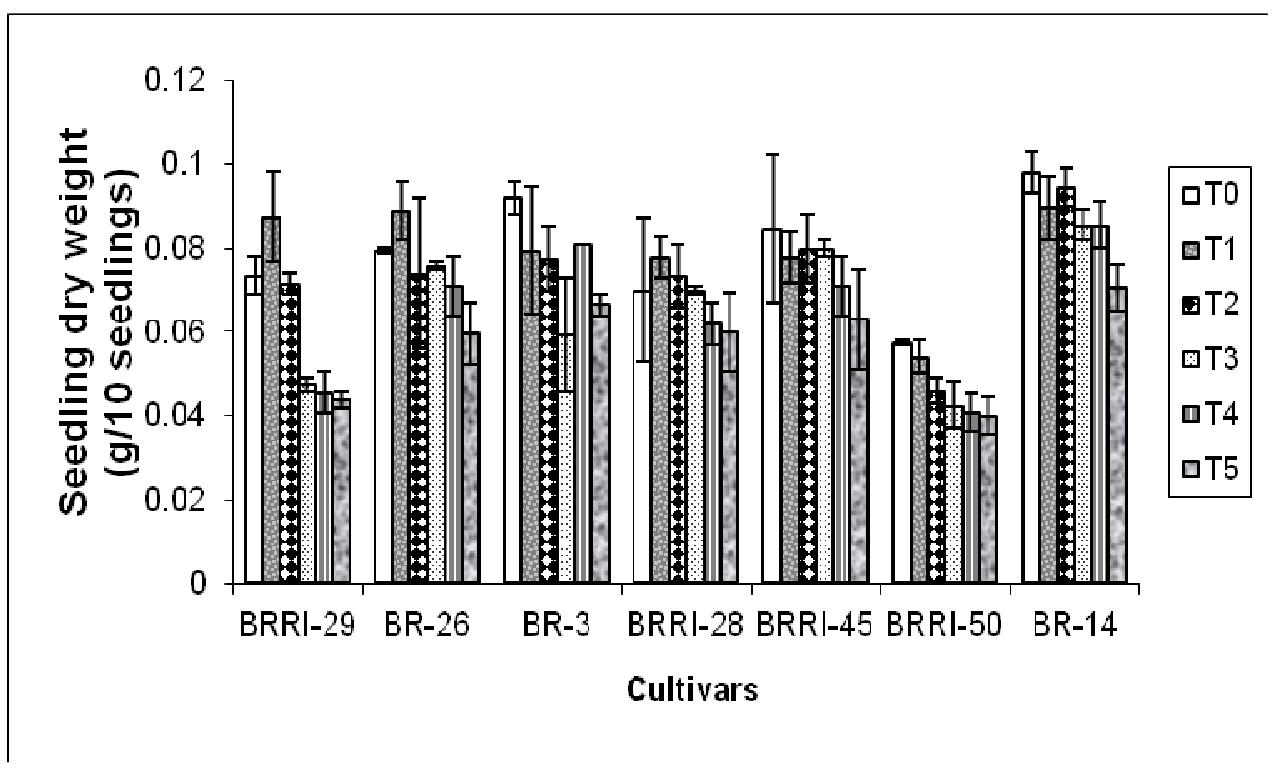

Fig. 1. Effect of different levels of arsenate on biomass or dry weight (g)/ ten seedlings of seven rice cultivars

\section{REFERENCES}

Abbas, H.H.M., Meharg, A.A. 2008. Arsenate, arsenite and dimethyl arsenic acid (DMA) uptake and tolerance in maize (Zea mays L.), Plant Soil. 304:277-289.

Abedin, M.J. and Meharg, A.A. 2002. Relative toxicity of arsenite and arsenate on germination and early seedling growth of rice (Oryza sativa L.), Plant Soil.243:5766.

Abedin, M.J., Cresser, M.S., Meharg, A.A. Feldman, J. and Cotter-Howells, J.2002b.Arsenic accumulation and metabolism in rice (Oryza sativa L.), Environ. Sci. Technol. 36 (5): 962-968.

Baker, S., Barrentine, W.L., Bowmann, D.H., Haawthorne, W.L. and Pettiet, J.V. 1976. Crop response and arsenic uptake following soil incorporation of MSMA, Weed Sci. 24: 322326.

Carbonell-Barrachina, A.A., Burlo-Carbonell, F. and Mataix-Beneyto, J. 1995. Arsenic uptake, distribution and accumulation in tomato plants: effect of arsenic on plant growth and yield, J. Plant Nutri. 18: 1237-1250.

Carbonell $\square$ Barrachina, A. A. and Burló $\square$ Carbonell, F. 1997. Effect of sodium arsenite and sodium chloride on bean plant nutrition (macronutrients), J. Plant Nutri. 20 (11):16171633.

Carbonell- Barrachina, A.A., Aarabi, M A., Delaune, R.D., Gambrell, R P. and Patrick, W.H. Jr. 1998. The influence of arsenic chemical from and concentration on Spartina patens and Spartinaalterniflora growth and tissue arsenic contents. Plant Soil. 198:33-43.

Cox, M.S., Bell, P.F. and Kovar, J.L. 1996.Different tolerance of canola to arsenic when grown hydroponically or in soil. J. Plant Nutri.19: 1599-1610.

Chun-xi, L., Shu-li, F., Yun, S., Li-na, J., Xu-yang, L. and Xiao-li, H. 2006. Effects of arsenic on seed germination and physiological activities of wheat seedlings. J. Environ. Sci. 19:725-732. 
European Virtual Institute for Speciation Analysis (EVISA). 2013. Arsenic species in rice: Origin, uptake and geographical variation. A report of European Virtual Institute for Speciation Analysis. pp.10-23.

Gomez, K.A. and Gomez, A.A. 1984. Statistical Procedures for Agricultural Research, $2^{\text {nd }}$ edn. John Wiley, New York.

Hertley-Whitaker, J., Ainswort, G. and Meharg, A.A. 2001. Copper and arsenate induced oxidative stress in Holcuslanatus L. Clones with different sensitivity, Plant Cell Environ. 24: 713722.

Hossain, M.B., Jahiruddin, M., Panauiiah, G.M., Loeppert, R.H., Islam, M.R. and Duxbury, J.M. 2008. Spatial variability of arsenic contamination in soils and plants, and its relationship with iron, manganese and phosphorus, Environ. Pollut.156: 739-744.

Jahan, L., Haque, S., Ullah, S.M. and Kibria, M.G. 2003a. Effects of Arsenic on some growth parameters of rice plant. Dhaka Univ. J. Biol. Sci. 12(1): 71-7

Marin, A.R., Masscheleyn, P.H. and Patrick Jr, W.H. 1992. The influence of chemical form and concentration of arsenic on rice growth and tissue arsenic concentration, Plant and Soil. 139: $175-183$.

Marin, A.R., Pezeshki, S.R., Masscheleyn, P.H. and Choi, H.S. 1993a. Effect of dimethylarsenicacid(DMAA) on growth, tissue arsenic and photosynthesis of rice plants, J. Plant Nutri.16:865-880.

Mascher, R., Lippmann, B., Holzinger, S. and Bergmann, H. 2002. Arsenic toxicity: effects on oxidative stress response molecules and enzymes in red clover plants. Plant Sci. 163: 961969.

Milam, M. R., Marin, A., Sedberry, J. E., Jr.Bligh, D. P. Sheppard, R. 1988. In: Annual Progress Report; Northeast Research Station and Macon Ridge Research Station: Baton Rouge, LA, pp. 105-108.

Marin, A. R.; Pezeshki, S. R.; Masscheleyn, P. H.; Choi, H. S. J. 1993a. Plant Nutr. 16:865-880.

Mitchell, P. and Barr, D. 1995. The nature and significance of public exposure to arsenic: a review of its relevance to south west England, J. Environ. Geochem.Health.17(2): 57-82.

Panaullah, G.M., Alam, T., Hossain, M.B., Loeppert, R.H., Lauren, J.G., Meisner, C.A., Ahmed, Z.U. and Duxbury, J.M. 2009.Arsenic toxicity to rice (Oryza sativa L.) in Bangladesh, Plant and Soil. 317: 31-39.

Panaullah, G.M., Duxbury, J.M., Zavala, Y.J., Alam, T., van Geen, L. and Lauren, J.G. 2013. Management practices to reduce arsenic toxicity to rice and plant arsenic concentrations.Abstract 0220-000327, 12th International Conference on the Biogeochemistry of Trace Elements ICOBTE, 16-20 June 2013 -Athens, Georgia, USA.

Rashid, H.A., Nath, D.K., Hossain, M., Khan, M.U., Shah, A.L., Saleque, M.A., Rahman, M.S. and Ghani, M.A. 2004. Variation of Arsenic content in groundwater with depth and river distance: GIS Mapping. In Proc. Arsenic in the food Chain: Assessment of arsenic in the water-soil-crop systems, 22 July 2004. BRRI, Gazipur. pp.53-71.

Ravenscroft, P., Burgess, W.L., Ahmed, K.M., Burren, M. and Perrin, J. 2005. Arsenic in groundwater of the Bengal Basin, Bangladesh: Distribution, field relations and hydrogeological setting. Hydrogeol. J. 13: 727-751.

Roberts, L.C., Hug, S.J., Dittmar, J., Voegolin, A. Saha, G.C., Ali, M.A., Badruzzaman, A.B.M. and Kretzschmar, R. 2007. Spatial distribution and temporal variability of arsenic in irrigated rice fields in Bangladesh. I. Irrigation Water. Environ. Sci. Technol. 41: 59605966.

Singh, N., Ma, L.Q., Srivastava, M. and Rathinasabapathi, B. 2006. Metabolic adaptations to arsenic-induced oxidative stress in Pterisvittata L. and Pterisensiformis L. Plant Sci.170: 274-282. 
Smedley, P.L. and Kinniburgh. 2002. A review of the source, behavior and distribution of arsenic in natural waters. App. Geochem.17: 517-568.

Srivastava, M., Ma, L.Q., Singh, N. and Singh, S. 2005. Antioxidant responses of hyperaccumulator and sensitive fern species to arsenic. J. Exp. Bot. 56: 1335-1342.

Swain, R.R. and Dekker, E.E. 1966a. Seed germination studies. I. Purification and properties of an $\alpha$-amylase from the cotyledons of germinating peas. Biochem. Biophys. Acta.122: 75-86.

Wang, J.R., Zhao, F.J. and Meharg, A.A. 2002. Mechanisms of arsenic hyperaccumulation in Pterisvittata uptake kineties, interactions with phosphate and arsenic speciation. J. Plant Physiol.130: 1552-1561.

William, P.N., Islam, S., Islam, M.R., Jahiruddin, M., Adomako, E., Solaiman, A.R.M., Rahman, G.K.M.M., Lu, Y., Deacon, C., Zhu, Y.G. and Meharg, A.A. 2009. Arsenic limits trace mineral nutrition (selenium, zinc and nickel) in Bangladesh rice grain, Environ. Sci. Technol.DOL: 10.1021/es901825t. 